\title{
PENGARUH KOMUNIKASI ORGANISASI DAN MOTIVASI TERHADAP KINERJA PEGAWAI PADA KANTOR DINAS SOSIAL DAN TENAGA KERJA KOTA PEMATANGSIANTAR
}

\author{
Oleh: \\ Surayani Lestari \\ S1 Manajemen \\ Darwin Lie, Marisi Butarbutar, Stefi Inggrid Thressa
}

Abstraksi

Adapun rumusan masalah penelitian ini adalah bagaimana pengaruh komunikasi organisasi dan motivasi terhadap kinerja pegawai pada Kantor Dinas Sosial dan Tenaga Kerja Kota Pematangsiantar baik secara simultan maupun parsial. Penelitian ini dilakukan dengan menggunakan desain penelitian lapangan dan kepustakaan. Jenis data yang digunakan adalah data kualitatif dan data kuantitatif. Sumber data dalam penelitian ini adalah data primer dan data sekunder. Populasi yang digunakan penulis dalam penelitian ini adalah sebanyak 38 responden yaitu pegawai pada Kantor Dinas Sosial dan Tenaga Kerja Kota Pematangsiantar. Pengumpulan data dilakukan dengan kuesioner, wawancara dan dokumentasi. Teknik analisis yang digunakan ialah regresi linier berganda, koefisien korelasi dan determinasi serta pengujian hipotesis dengan uji $\mathrm{F}$ dan uji $\mathrm{t}$.

Hasil penelitian dapat disimpulkan sebagai berikut: 1. Komunikasi organisasi yang diterapkan sudah setuju dan pegawai sangat setuju dengan motivasi yang diberikan serta kinerja pegawai sudah sangat baik. 2 . Hasil analisis regresi adalah $\hat{\mathrm{Y}}=54,905+0,805 \mathrm{X}_{1}+0,902 \mathrm{X}_{2}$, artinya komunikasi organisasi dan motivasi berpengaruh positif terhadap kinerja pegawai. 3 . Hasil analisis korelasi diperoleh nilai $r=0,841$ artinya hubungan komunikasi organisasi, motivasi dengan kinerja pegawai sangat kuat dan positif. Tinggi rendahnya kinerja pegawai dapat dijelaskan oleh komunikasi organisasi dan motivasi sebesar 70,6\%. 4. Hipotesis penelitian $\mathrm{H}_{0}$ ditolak, artinya komunikasi organisasi dan motivasi berpengaruh positif dan signifikan terhadap kinerja pegawai pada Kantor Dinas Sosial dan Tenaga Kerja Kota Pematangsiantar baik secara simultan maupun parsial.

Adapun saran dari penelitian ini adalah untuk meningkatkan komunikasi organisasi, diperlukan sikap peduli pimpinan terhadap masalah pegawai, dan pegawai lebih mempererat hubungan komunikasi dengan rekan kerja. Dalam meningkatkan motivasi, perlu dilakukan pemberian apresiasi kepada para pegawai yang berprestasi, dan mendukung pegawai untuk mengikuti pendidikan dan pelatihan kerja. Dalam meningkatkan kinerja, pegawai lebih teliti dalam melaksanakan pekerjaan dan meningkatkan rasa tanggungjawabnya terhadap pekerjaan.

Kata kunci: Komunikasi Organisasi, Motivasi, dan Kinerja Pegawai.

\section{Abstraction}

As for this research problem formula is how organizational communication and motivation influence to employee performance at the Kantor Dinas Sosial dan Tenaga Kerja Kota Pematangsiantar its good in simultaneous and partial. This research has done by using literature and field research. The data used is qualitative and quantitative data. Sources of data in this study are primary data and secondary data. The population using by writer is 38 respond they are employees of Kantor Dinas Sosial dan Tenaga Kerja Kota Pematangsiantar, collecting data done by questioner, interview and documentation. The analysis technique done by regression multiple linear, coefficient correlation and determination with testing hypothesis with test $F$ and test $t$.

The result of this research can be conclude: 1. Communication organization that implemented is agreed and the employees very agree with the motivation given and employee performance has been very good. 2 . The results of regression analysis is $\hat{\mathrm{Y}}=54,905+0,805 \mathrm{X}_{1}+0,902 \mathrm{X}_{2}$, meaning organizational communication and motivation positive influence for employee performance. 3. The result of analysis correlations get value $r=$ 0,841 it's means that the relation of organizational communication, motivation with employee performance is very strong and positive. The higher and lower of employee performance can explain by organizational communication and motivation as big as 70,6\%. 4. Hypothesis research $H_{0}$ rejected, it's means the organizational communication and motivation is positive influence and significant for employee performance at the Kantor Dinas Sosial dan Tenaga Kerja Kota Pematangsiantar its good in simultaneous and partial.

The suggestions from this research is to improve organizational communication, needed caring attitude leader to the problem of employee and employee communication more strengthen relationship with colleagues. To enhance motivation, needs to be done giving appreciation to employees who excel, and support employees to participate in education and job training. In improving performance, the employee should be more careful in carrying out the work and increase the sense of responsibility towards work.

Keyword: $\quad$ Organizational Communication, Motivation, and Employee Performance. 


\section{A. PENDAhuluan}

1.Latar Belakang Masalah

Dinas Sosial dan Tenaga Kerja Kota Pematangsiantar merupakan sebuah organisasi pemerintahan yang memiliki visi yaitu: Terwujudnya Tenaga Kerja Yang Produktif dan Masyarakat Yang Sejahtera. Agar visi tersebut dapat terwujud, maka dibutuhkan pengelolaan manajemen yang baik dari segi manajemen sumber daya manusianya. Dinas Sosial dan Tenaga Kerja Kota Pematangsiantar menyadari bahwa untuk dapat mencapai tujuan yang diinginkan, diperlukan sumber daya manusia yang memiliki kinerja yang baik.

Kinerja pegawai merupakan prestasi aktual yang dicapai pegawai dalam melakukan suatu aktivitas kerja pada periode tertentu. Adapun fenomena kinerja pegawai yang ada pada Dinas Sosial dan Tenaga Kerja Kota Pematangsiantar belum optimal. Dimensi kinerja pada Dinas Sosial dan Tenaga Kerja Kota Pematangsiantar diketahui berdasarkan Sasaran Kerja Pegawai (SKP) yang terdiri dari kuantitas, kualitas, waktu, dan biaya. Sedangkan pada Perilaku Kerja (PK) yang terdiri dari orientasi pelayanan, integritas, komitmen, disiplin, kerjasama, dan kepemimpinan. Berikut ini adalah fenomena kinerja pegawai yang ada pada Kantor Dinas Sosial dan Tenaga Kerja Kota Pematangsiantar.

Tabel 1

Dimensi Kinerja Pegawai pada Kantor Dinas Sosial dan

Tenaga Kerja Kota Pematangsiantar

\begin{tabular}{|c|c|c|c|c|c|c|}
\hline DImenal KInerjọ Pag awal & 58 & в & ᄃB & T日 & STE & tymlsh \\
\hline KuERt=s & 985 & $32 \%$ & $23 \% / 3$ & $0 \%$ & T\% & $10 \mathrm{WS}$ \\
\hline Kilsititas: & $4 \geqslant \%$ & $34 \%$ & 2435 & $\mathrm{~B}: \mathrm{h}$ & $\mathrm{A}_{\mathrm{h}}^{\mathrm{h}}$ & 1anes \\
\hline Wyklu & $36 \mathrm{k}$ & $35 \%$ & $28 \%$ & $0 x_{0}^{2}$ & $0 \%$ & $100 \%$ \\
\hline$\sqrt{\mathrm{B} \times \mathrm{x} \times \mathrm{W}}$ & $30 \%$ & $46 \mathrm{~s}$ & $202 / 2$ & $61 \%$ & $9 \% 0$ & $100 \%$ \\
\hline 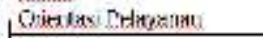 & $543 \mathrm{i}$ & $m m_{1}$ & $18 \%$ & $03 \mathrm{in}$ & $n_{\mathrm{iti}}$ & $1 a m_{1}$ \\
\hline Thisculyn & एखस & $81 \%$ & $28 \%$ & 010 & 910 & $100 \%$ \\
\hline | Kantman & 413 & $44 \mathrm{w}$ & 1:1:2h & (1) & $1 \% \mathrm{~m}$ & 10 ans \\
\hline Cirilin & $35 x$ & $3 \% \%$ & $20 \% / 2$ & OR: & $a_{i}$ & $100 \%$ \\
\hline Kackestata & अंस & $13 \%$ & $2 / 2 / 2$ & $01 \%$ & $5 \%$ & $100 \%$ \\
\hline Kammorimajna & $273:$ & mas & 2334 & $n ? h$ & $\Omega_{\mathrm{n}}$ & $100 \%$ \\
\hline
\end{tabular}

Sumber: hasil wawancara dengan Sekretaris SKPD (Mei 2016)

Pada tabel 1 di atas, diketahui bahwa kinerja pegawai pada Kantor Dinas Sosial dan Tenaga Kerja Kota Pematangsiantar belum optimal, hal ini dapat dilihat dari adanya persentase yang cukup baik pada tabel di atas. Kinerja pegawai menjadi hal yang perlu diperhatikan dengan cukup serius oleh organisasi, karena kinerja pegawai dengan segala aspek yang ada didalamnya akan memberikan dampak secara langsung terhadap organisasi. Salah satu faktor yang dapat mempengaruhi kinerja pegawai adalah komunikasi organisasi. Komunikasi yang ada pada organisasi harus dikelola se-efektif dan se-efisien mungkin agar pegawai lebih antusias dalam bekerja, sehingga akan menghasilkan kinerja yang optimal.

Dinas Sosial dan Tenaga Kerja Kota Pematangsiantar mengelola komunikasi sebagai upaya menghasilkan kinerja yang optimal dengan cara memberikan arahan kepada pegawainya, baik pada saat apel (upacara) maupun pada saat rapat, yang isinya memberitahukan bahwa setiap pegawai harus mampu bekerjasama dengan baik agar tercipta hubungan kerja yang harmonis. Hubungan kerja para pegawai Dinas Sosial dan Tenaga Kerja Kota Pematangsiantar yang kurang harmonis disebabkan oleh jalinan komunikasi yang kurang baik, karena setiap pegawai memiliki kesibukan tersendiri sehingga menyebabkan kurangnya waktu untuk saling berkomunikasi.

Di samping faktor komunikasi organisasi, faktor motivasi juga dapat mempengaruhi kinerja pegawai. Dinas Sosial dan Tenaga Kerja Kota Pematangsiantar mengelola motivasi sebagai upaya menghasilkan kinerja yang optimal dengan cara memberikan penghargaan kepada pegawai yang memiliki kreativitas dan berprestasi dalam bekerja. Adapun bentuk penghargaan yang diberikan, yaitu: pengusulan kenaikan gaji berkala, pengusulan kenaikan pangkat, dan memberi kesempatan kepada setiap pegawai untuk dapat mengikuti pelatihan yang sesuai dengan tugas pokok dan fungsi (tupoksi).

\section{Rumusan Masalah}

a. Bagaimana gambaran komunikasi organisasi, pemberian motivasi, dan kinerja pegawai pada Kantor Dinas Sosial dan Tenaga Kerja Kota Pematangsiantar.

b. Bagaimana pengaruh komunikasi organisasi dan motivasi terhadap kinerja pegawai pada Kantor Dinas Sosial dan Tenaga Kerja Kota Pematangsiantar baik secara simultan maupun parsial.

\section{Tujuan Penelitian}

a. Untuk mengetahui gambaran komunikasi organisasi, pemberian motivasi, dan kinerja pegawai pada Kantor Dinas Sosial dan Tenaga Kerja Kota Pematangsiantar.

b. Untuk mengetahui pengaruh komunikasi organisasi dan motivasi terhadap kinerja pegawai pada Kantor Dinas Sosial dan Tenaga Kerja Kota Pematangsiantar baik secara simultan maupun parsial.

\section{Metode Penelitian}

Yang menjadi objek penelitian adalah Kantor Dinas Sosial dan Tenaga Kerja Kota Pematangsiantar yang terletak di Jalan Dahlia No. 24 Telepon (0622) 22205 Pematangsiantar. Populasi adalah seluruh pegawai negeri sipil yang berada pada Kantor Dinas Sosial dan Tenaga Kerja Kota Pematangsiantar yaitu sebanyak 38 pegawai.

Adapun desain penelitian yang digunakan dalam penulisan skripsi ini adalah Penelitian Kepustakaan (Library Research) dan Penelitian Lapangan (Field Research). Teknik pengumpulan data yang dilakukan penulis dalam penelitian ini adalah berupa Kuesioner, Wawancara dan Dokumentasi. Jenis data yang digunakan dalam penelitian ini adalah jenis data kualitatif dan data kuantitatif. Hasil data yang diperoleh dari lapangan akan dianalisis secara deskriptif baik bersifat kualitatif dan kuantitatif. 


\section{B. LANDASAN TEORI}

1. Manajemen Sumber Daya Manusia

Menurut Bangun (2012:6), manajemen sumber daya manusia dapat didefinisikan sebagai suatu proses perencanaan, pengorganisasian, penyusunan staf, penggerakan, dan pengawasan terhadap pengadaan, pengembangan, pemberian kompensasi, pengintegrasian, pemeliharaan, dan pemisahan tenaga kerja untuk mencapai tujuan organisasi. Sedangkan menurut Mondy (2008:4), manajemen sumber daya manusia adalah pemanfaatan sejumlah individu untuk mencapai tujuan-tujuan organisasi. Berdasarkan pendapat para ahli di atas, penulis mengambil kesimpulan bahwa manajemen sumber daya manusia adalah suatu proses perencanaan, pengorganisasian, penyusunan staf, penggerakan, dan pengawasan dengan memanfaatkan sejumlah individu untuk mencapai tujuan organisasi.

\section{Komunikasi Organisasi}

Menurut Menurut Robbins dan Mary (2010:88), menyatakan komunikasi organisasi adalah komunikasi yang berlangsung dalam aturan-aturan kerja organisasi yang ditetapkan. Sedangkan menurut Pace dan Don (2006:31), komunikasi organisasi dapat didefinisikan sebagai pertunjukan dan penafsiran pesan diantara unit-unit komunikasi yang merupakan bagian dari suatu organisasi tertentu. Berdasarkan pendapat para ahli di atas, penulis mengambil kesimpulan bahwa komunikasi organisasi adalah komunikasi yang berlangsung dalam lingkungan organisasi secara timbal balik dalam rangka mencapai tujuan yang telah ditetapkan.

Menurut Pace dan Don (2006:184), arah aliran informasi dalam organisasi meliputi: Komunikasi ke bawah, Komunikasi ke atas, komunikasi horizontal, dan komunikasi lintas saluran. Sedangkan menurut Bangun (2012:367), komunikasi dalam organisasi dapat mengalir secara vertikal dan horizontal. Komunikasi secara vertikal dapat dibagi menjadi arah ke bawah dan ke atas. Berdasarkan pendapat para ahli di atas, penulis menyimpulkan bahwa pola komunikasi dalam organisasi meliputi: komunikasi ke bawah, komunikasi ke atas, komunikasi horizontal, dan komunikasi lintas saluran.

\section{Motivasi}

Menurut Handoko (2002:252), motivasi diartikan sebagai keadaan dalam pribadi seseorang yang mendorong keinginan individu untuk melakukan kegiatan-kegiatan tertentu guna mencapai tujuan. Robbins (2003:156), mendefinisikan motivasi sebagai proses yang menyebabkan intensitas (intensity), arah (direction), dan usaha terus menerus (persistence) individu menuju pencapaian tujuan. Berdasarkan pendapat para ahli di atas, penulis menyimpulkan bahwa motivasi adalah keinginan dalam diri seseorang untuk melakukan kegiatankegiatan tertentu guna mencapai tujuan.

Menurut Bangun (2012:325), teori motivasi McClelland terbagi menjadi tiga yaitu motivasi berprestasi, motivasi berkuasa, dan motivasi afiliasi. Menurut Luthans (2006:279), teori motivasi dapat dikelompokkan ke dalam tiga kategori yaitu: teori kepuasan, teori proses, dan teori kontemporer. Berdasarkan pendapat para ahli di atas, penulis menyimpulkan bahwa teori kebutuhan McClelland terdiri dari tiga kebutuhan yaitu: kebutuhan untuk berprestasi (need for achievement), kebutuhan untuk berafiliasi (need for affiliation), dan kebutuhan untuk berkuasa (need for power). Seseorang yang tergolong pada high achiever harus diberikan pekerjaan yang menantang dengan sasaran akhir yang masih dapat dicapai. Bagi mereka uang bukanlah suatu motivator yang penting, yang terpenting adalah umpan balik atas pekerjaan yang telah mereka lakukan; seseorang dengan kebutuhan afiliasi yang tinggi membutuhkan lingkungan kerja yang dipenuhi dengan nuansa kerjasama yang prima; dan seseorang dengan kebutuhan kekuasaan yang tinggi membutuhkan peluang untuk dapat mengatur orang lain di dalam organisasi.

\section{Kinerja Pegawai}

Menurut Gomes (2003:39), kinerja pegawai dinyatakan sebagai catatan hasil produksi pada fungsi pekerjaan yang spesifik atau aktivitas pada periode tertentu. Sehingga kinerja merupakan tingkat keberhasilan yang diraih oleh pegawai dalam melakukan suatu aktivitas kerja dan merujuk pada tugas yang harus dilakukan. Sedangkan menurut Dessler (2004:78), kinerja pegawai adalah prestasi aktual pegawai dibandingkan dengan prestasi yang diharapkan dari pegawai. Prestasi kerja yang diharapkan adalah prestasi standar yang disusun sebagai acuan sehingga dapat melihat kinerja pegawai sesuai dengan posisinya dibandingkan standar yang dibuat. Berdasarkan pengertian di atas, maka dapat disimpulkan bahwa kinerja pegawai adalah prestasi aktual pegawai dalam melakukan suatu aktivitas kerja pada periode tertentu.

Menurut Mathis dan John (2006:378), kinerja karyawan yang umum untuk kebanyakan pekerjaan meliputi elemen sebagai berikut: kuantitas dari hasil, kualitas dari hasil, ketetapan waktu dari hasil, kehadiran, dan kemampuan bekerjasama. Presiden Republik Indonesia sudah mengeluarkan aturan mengenai sasaran kerja pegawai (SKP) yaitu Peraturan Pemerintah Republik Indonesia Nomor 46 Tahun 2011 Tentang Penilaian Prestasi Kerja Pegawai Negeri Sipil. Menurut Pasal 1 ayat (2) PP No. 46 Tahun 2011. Penilaian prestasi kerja tersebut terdiri dari dua unsur yakni: sasaran kerja pegawai (SKP) dan perilaku kerja (PK) dengan bobot penilaian masing-masing unsur SKP $60 \%$ dan perilaku kerja sebesar $40 \%$. Secara umum, penilaian prestasi kerja pegawai negeri sipil terbagi dalam 2 (dua) unsur yaitu pertama Sasaran Kerja Pegawai (SKP) yang meliputi: kuantitas, kualitas, waktu, dan biaya. Yang kedua adalah perilaku kerja yang meliputi: orientasi pelayanan, integritas, komitmen, disiplin, kerjasama, dan kepemimpinan. Berdasarkan uraian di atas, maka dapat disimpulkan bahwa dimensi kinerja pegawai merupakan suatu alat yang 
digunakan oleh organisasi untuk mengukur kinerja seorang pegawai.

\section{PEMBAHASAN}

\section{Analisa}

\section{a. Deskriptif Kualitatif}

Analisis deskriptif kualitatif dimaksudkan untuk mendapatkan gambaran atau deskripsi mengenai tanggapan dari pegawai mengenai Pengaruh Komunikasi Organisasi dan Motivasi terhadap Kinerja Pegawai pada Kantor Dinas Sosial dan Tenaga Kerja Kota Pematangsiantar. Adapun penetapan kriteria nilai rata-rata jawaban dari responden tersebut dimasukkan kedalam kelas-kelas interval dimana penentuan intervalnya memakai rumus sebagai berikut:

Interval Kelas $=\underline{\text { Nilai Tertinggi }- \text { Nilai Terendah }}$

$$
\text { Jumlah Kelas }
$$

Dari rumus di atas dapat diperoleh interval kelas 0,8 sehingga berlaku ketentuan indikator dengan hasil sebagai berikut:

Tabel 2

Nilai Interval dan Indikator Jawaban Responden

\begin{tabular}{|c|c|c|c|}
\hline \multirow{2}{*}{$\begin{array}{c}\text { Nilai } \\
\text { Interval }\end{array}$} & \multicolumn{3}{|c|}{ Indikator } \\
\cline { 2 - 4 } & Komunikasi & Disiplin kerja & Kinerja Kerja \\
\hline $1,00-1,80$ & Sangat Tidak Baik & $\begin{array}{c}\text { Sangat Tidak } \\
\text { Baik }\end{array}$ & $\begin{array}{c}\text { Sangat Tidak } \\
\text { Baik }\end{array}$ \\
\hline $1,81-2,60$ & Tidak Baik & Tidak Baik & Tidak Baik \\
\hline $2,61-3,40$ & Cukup Baik & Cukup Baik & Cukup Baik \\
\hline $3,41-4,20$ & Baik & Baik & Baik \\
\hline $4,21-5.00$ & Sangat Baik & Sangat Baik & Sangat Baik \\
\hline
\end{tabular}

Sumber : hasil pengolahan data

\section{1) Gambaran Komunikasi Organisasi Pada} Kantor Dinas Sosial dan Tenaga Kerja Kota Pematangsiantar

Dari hasil analisa, untuk dimensi komunikasi ke bawah pada indikator penyampaian pesan dari atasan saat rapat berada pada rata-rata 4,03 dengan kriteria jawaban setuju, disebabkan pegawai paham akan maksud dari pesan yang disampaikan oleh pimpinan dan dapat melaksanakannya dengan baik. Demikian juga pada indikator penyampaian instruksi dari atasan berada pada rata-rata 4,16 dengan kriteria jawaban setuju akan pernyataan tersebut, disebabkan pegawai dapat menyelesaikan setiap instruksi kerja yang diberikan oleh pimpinan dengan baik. Pada indikator pengarahan dari atasan berada pada ratarata 4,26 dengan kriteria jawaban sangat setuju, disebabkan pimpinan sangat menghargai tanggapan dari setiap pegawai dan pimpinan senantiasa memberikan pengarahan kepada pegawai atas tanggapan tersebut.

Demikian juga pada dimensi komunikasi ke atas pada indikator informasi yang disampaikan oleh pegawai berada pada rata-rata 4,03 dengan kriteria jawaban setuju, disebabkan pegawai menginformasikan hasil kerjanya kepada atasan dengan baik dan sesuai dengan prosedur kerja. Untuk indikator penyampaian masalah pegawai memperoleh nilai rata-rata 4,05 dengan kriteria jawaban setuju, disebabkan pegawai merasa tidak sungkan untuk meminta saran dari pimpinan saat mengalami kesulitan dalam bekerja. Pada indikator partisipasi pegawai pada saat rapat berada pada rata- rata 4,13 dengan kriteria jawaban setuju, disebabkan pegawai mampu untuk berperan aktif menyumbangkan pendapatnya pada saat rapat.

Selanjutnya untuk dimensi komunikasi horizontal pada indikator interaksi antara rekan kerja satu bagian berada pada rata-rata 4,23 dengan kriteria jawaban sangat setuju, hal ini disebabkan para pegawai di dalam unit kerja yang sama saling berinteraksi dengan baik. Pada indikator kerjasama menyelesaikan pekerjaan dengan rekan kerja satu bagian berada pada rata-rata 4,21 dengan kriteria jawaban sangat setuju, hal ini disebabkan pegawai mampu bekerjasama dengan sesama rekan satu unit kerjanya. Untuk indikator berbagi informasi pekerjaan kepada rekan kerja satu bagian berada pada rata-rata 4,28 dengan kriteria jawaban sangat setuju, hal ini disebabkan pegawai selalu berbagi informasi pekerjaan dengan sesama rekan satu unit kerjanya.

Berikutnya untuk dimensi komunikasi lintas saluran pada indikator interaksi dengan rekan kerja di bagian lain berada pada rata-rata 3,97 dengan kriteria jawaban setuju, hal ini disebabkan pegawai dapat berinteraksi baik dengan pegawai di luar unit kerjanya. Pada indikator tegur sapa apabila bertemu dengan rekan kerja di bagian lain berada pada ratarata 4,21 dengan kriteria jawaban sangat setuju, hal ini disebabkan pegawai saling menghormati rekan kerjanya sehingga pegawai saling bertegur sapa apabila bertemu dengan rekan kerjanya. Untuk indikator bertukar pikiran dengan rekan kerja di bagian lain apabila ada hal yang perlu untuk ditindak lanjuti berada pada rata-rata 4,07 dengan kriteria jawaban setuju, hal ini disebabkan pegawai saling bekerjasama guna menyelesaikan hal-hal yang perlu untuk ditindak lanjuti dalam pekerjaan.

\section{2) Gambaran Motivasi Pada Kantor Dinas Sosial} dan Tenaga Kerja Kota Pematangsiantar

Dari hasil analisa, dapat dijelaskan untuk dimensi kebutuhan akan prestasi pada indikator potensi yang dimiliki dalam bekerja demi mencapai prestasi kerja berada pada rata-rata 4,71 dengan kriteria jawaban sangat setuju, hal ini disebabkan para pegawai mengeluarkan semua potensinya dalam bekerja. Pada indikator kreativitas dalam bekerja berada pada rata-rata 4,34 dengan kriteria jawaban sangat setuju, hal ini disebabkan pegawai mengeluarkan kreativitasnya dalam bekerja. Demikian juga pada indikator prestasi di tempat kerja berada pada rata-rata 4,13 dengan kriteria jawaban setuju, hal ini disebabkan pegawai memiliki prestasi yang baik di tempat kerja.

Selanjutnya pada dimensi kebutuhan akan afiliasi dengan indikator hasil kerja mendapat apresiasi dari pimpinan berada pada rata-rata 4,42 dengan kriteria jawaban sangat setuju, hal ini disebabkan pegawai telah memperoleh bentuk apresiasi dari pimpinan atas keberhasilannya dalam bekerja. Pada indikator setiap ide yang diberikan dalam pekerjaan dihargai oleh pimpinan berada pada rata-rata 4,50 dengan kriteria jawaban sangat setuju, hal ini disebabkan setiap ide yang diberikan oleh 
pegawai selalu dihargai oleh pimpinan. Pada indikator kerjasama dengan rekan kerja berada pada rata-rata 4,21 dengan kriteria jawaban sangat setuju, hal ini disebabkan pegawai mampu bekerjasama dengan baik antar sesama rekan kerja. Kemudian pada indikator rasa bangga mengerjakan pekerjaan apapun tanpa harus takut gagal berada pada rata-rata 4,44 dengan kriteria jawaban sangat setuju.

Demikian juga halnya dengan dimensi kebutuhan akan kekuasaan pada indikator kesanggupan menghadapi tantangan pekerjaan untuk meraih jabatan tertentu berada pada rata-rata 4,15 dengan kriteria jawaban setuju, hal ini disebabkan pegawai dibekali dengan wawasan dan pengetahuan sehingga pegawai sanggup untuk menghadapi tantangan pekerjaan. Pada indikator dukungan untuk dapat naik pangkat dari pimpinan berada pada ratarata 4,55 dengan kriteria jawaban sangat setuju, hal ini disebabkan pimpinan selalu memberikan kesempatan kepada pegawai untuk dapat naik pangkat. Pada indikator usaha mengikuti perkembangan IPTEK (ilmu pengetahuan dan teknologi) dalam menghadapi persaingan untuk meraih jabatan tertentu berada pada rata-rata 4,31 dengan kriteria jawaban sangat setuju, hal ini disebabkan hampir seluruh pegawai telah memiliki kemampuan teknologi yang tinggi untuk bersaing dalam meraih jabatan tertentu.

\section{3) Gambaran Kinerja Pegawai Pada Kantor Pelayanan Kekayaan Negara dan Lelang Pematangsiantar}

Dari hasil analisa, dapat diketahui bahwa pada dimensi kuantitas dengan indikator tingkat pencapaian target kerja berada pada nilai rata-rata 4,42 dengan kriteria jawaban sangat baik, hal ini disebabkan pegawai memiliki antusias untuk mencapai target kerja yang baik. Selanjutnya indikator tentang pertanggung jawaban hasil kerja berada pada nilai rata-rata 4,23 dengan kriteria jawaban sangat baik, hal ini disebabkan para pegawai Kantor Dinas Sosial dan Tenaga Kerja Kota Pematangsiantar bertanggung jawab akan pekerjaan yang telah di berikan kepadanya. Kemudian, pada indikator tingkat pencapaian tupoksi berada pada nilai rata-rata 4,50 dengan kriteria jawaban sangat baik, hal ini disebabkan para pegawai sangat berantusias untuk melaksanakan tugas pokok dan fungsinya (tupoksi).

Untuk dimensi kualitas pada indikator tingkat mutu hasil kerja berada pada nilai rata-rata 4,18 dengan kriteria jawaban baik, hal ini disebabkan pegawai dapat menyelesaikan pekerjaannya dengan efektif dan efisien. Selanjutnya indikator tentang ketelitian dalam bekerja responden memberikan nilai rata-rata 4,39 dengan kriteria jawaban sangat baik, hal ini disebabkan para pegawai sangat teliti dalam mengerjakan tugas yang telah diberikan kepadanya. Pada indikator kerapian dalam bekerja berada pada nilai rata-rata 4,42 dengan kriteria jawaban sangat baik, hal ini disebabkan pegawai Kantor Dinas Sosial dan Tenaga Kerja Kota Pematangsiantar sangat terampil dalam menyelesaikan pekerjaan yang diberikan kepadanya.

Selanjutnya untuk dimensi waktu pada indikator tepat waktu berada pada nilai rata-rata 4,47 dengan kriteria jawaban sangat baik, hal ini disebabkan pegawai dalam menyelesaikan suatu pekerjaaan sesuai dengan target waktu yang telah ditentukan. Pada indikator efisiensi waktu berada pada nilai rata-rata jawaban 4,74 dengan kriteria jawaban sangat baik, hal ini disebabkan para pegawai bersaing secara positif untuk menyelesaikan pekerjaan mereka masing-masing. Selanjutnya pada indikator ketepatan waktu kehadiran pegawai berada pada nilai rata-rata 4,65 dengan kriteria jawaban sangat baik, hal ini disebabkan hampir seluruh pegawai datang ke kantor dengan tepat waktu.

Untuk dimensi biaya pada indikator kemampuan mengalokasikan biaya berada pada nilai rata-rata 4,57 dengan kriteria jawaban sangat baik, hal ini disebabkan anggaran biaya yang diberikan kepada setiap pegawai untuk melakukan pekerjaannya digunakan dengan sebaik mungkin. Pada indikator jumlah anggaran yang diberikan pada rata-rata jawaban 4,47 dengan kriteria jawaban sangat baik, hal ini disebabkan anggaran yang diberikan instansi sesuai dengan kebutuhan yang diperlukan. Selanjutnya pada indikator pertanggungjawaban dalam menyusun anggaran berada pada nilai rata-rata 4,63 dengan kriteria jawaban sangat baik, hal ini disebabkan anggaran biaya yang diberikan untuk keperluan pekerjaan dialokasikan dengan tepat.

Sementara pada dimensi orientasi pelayanan pada indikator tingkat pelayanan berada pada nilai rata-rata 4,23 dengan jawaban kriteria sangat baik, hal ini disebabkan pegawai Kantor Dinas Sosial dan Tenaga Kerja Kota Pematangsiantar memberikan pelayanan sebaik mungkin kepada masyarakat. Pada indikator sikap dalam memberi pelayanan berada pada nilai rata-rata 4,60 dengan kriteria jawaban sangat baik, hal ini disebabkan setiap pegawai mampu memberikan pelayanan yang terbaik kepada masyarakat maupun kepada instansi lain. Pada indikator perilaku dalam memberi pelayanan berada pada nilai rata-rata 4,76 dengan kriteria jawaban sangat baik, hal ini disebabkan pegawai selalu berperilaku baik saat memberikan pelayanan kepada masyarakat maupun instansi lain.

Selanjutnya dimensi integritas pada indikator konsistensi dalam bekerja berada pada nilai rata-rata jawaban 4,84 dengan kriteria jawaban sangat baik, hal ini disebabkan pegawai Kantor Dinas Sosial dan Tenaga Kerja Kota Pematangsiantar sangat konsisten dalam melaksanakan pekerjaan. Pada indikator etika dalam bekerja berada pada nilai rata-rata 4,60 dengan kriteria jawaban sangat baik, hal ini disebabkan pegawai memiliki etika yang baik dalam bekerja dan dalam berperilaku. Pada indikator kemampuan dalam bertindak berada pada nilai ratarata 4,57 dengan kriteria jawaban sangat baik, hal ini disebabkan pegawai dapat melaksanakan setiap pekerjaan yang diberikan dengan baik. 
Untuk dimensi komitmen pada indikator tingkat kemauan dalam menyelesaikan pekerjaan berada pada nilai rata-rata 4,47 dengan kriteria jawaban sangat baik, hal ini disebabkan kemauan pegawai dalam bekerja sangat tinggi. Pada indikator tanggung jawab dalam bekerja berada pada nilai rata-rata 4,52 dengan kriteria jawaban sangat baik, hal ini disebabkan pegawai siap bertanggung jawab dalam segala pekerjaan yang dilakukannya. Demikian juga pada indikator komitmen terhadap organisasi berada pada nilai rata-rata 4,52 dengan kriteria jawaban sangat baik, hal ini disebabkan pegawai selalu menjaga nama baik Kantor Dinas Sosial dan Tenaga Kerja Kota Pematangsiantar.

Selanjutnya pada dimensi disiplin dengan indikator tingkat kehadiran pegawai berada pada nilai rata-rata 3,95 dengan kriteria jawaban baik, hal ini disebabkan pegawai memiliki rasa tanggungjawab terhadap pekerjaannya. Pada indikator kepatuhan dalam menaati peraturan berada pada nilai rata-rata 4,68 dengan kriteria jawaban sangat baik, hal ini disebabkan pegawai sangat mematuhi peraturan-peraturan yang telah ditetapkan oleh instansi. Kemudian, pada indikator kesanggupan menghindari larangan berada pada nilai rata-rata 4,52 dengan kriteria jawaban sangat baik, hal ini disebabkan para pegawai selalu bekerja sesuai dengan prosedur yang berlaku.

Untuk dimensi kerjasama pada indikator kerjasama dengan rekan kerja satu bagian berada pada nilai rata-rata 4,39 dengan kriteria jawaban sangat baik, hal ini disebabkan pegawai di dalam unit kerja yang sama saling bekerjasama dengan baik. Pada indikator kerjasama dengan rekan kerja bagian lain berada pada nilai rata-rata 4,39 dengan kriteria jawaban sangat baik, hal ini disebabkan para pegawai selalu menjaga hubungan yang baik antar pegawai. Demikian juga pada indikator kerjasama dengan pimpinan berada pada nilai rata-rata 4,68 dengan kriteria jawaban sangat baik, hal ini disebabkan pegawai memiliki hubungan yang sangat baik dengan pimpinan.

Pada dimensi kepemimpinan pada indikator kemampuan meyakinkan pegawai lain untuk melaksanakan tugas pokok berada pada nilai ratarata 4,37 dengan kriteria jawaban sangat baik, hal ini disebabkan pegawai yang menduduki suatu jabatan tertentu memiliki wewenang untuk meyakinkan pegawai yang lain untuk melaksanakan tugas pokoknya. Selanjutnya pada indikator kemampuan meyakinkan pegawai lain untuk melaksanakan tugas tambahan berada pada nilai rata-rata 4,00 dengan kriteria jawaban baik, hal ini disebabkan pegawai memiliki hubungan kerja yang baik dengan rekan kerjanya sehingga pegawai mampu meyakinkan rekan kerjanya untuk melaksanakan tugas tambahan. Sedangkan pada indikator kemampuan memimpin rapat saat diperlukan berada pada nilai rata-rata 4,50 dengan kriteria jawaban sangat baik, hal ini disebabkan masing-masing pegawai telah dibekali oleh pengetahuan dan memiliki persiapan diri yang baik sehingga pegawai akan siap sedia apabila diperlukan untuk memimpin rapat.

\section{b. Deskriptif Kuantitatif}

1) Regresi Linear Berganda

Analisis data dalam penelitian ini menggunakan analisis regresi linier berganda. Analisis regresi linier berganda digunakan untuk mengetahui pengaruh variabel bebas (X) dan variabel terikat (Y). X adalah komunikasi organisasi, motivasi dan $\mathrm{Y}$ adalah kinerja pegawai. Analisis dijalankan dengan melakukan tabulasi jawaban responden pada kuesioner yang telah dijalankan. Maka dilakukan perhitungan mengunakan program aplikasi SPSS untuk memperoleh nilai a dan $b$ dengan notasi sebagai berikut:

Tabel 3

Hasil Regresi Linier Berganda Coefficients $^{\mathrm{a}}$

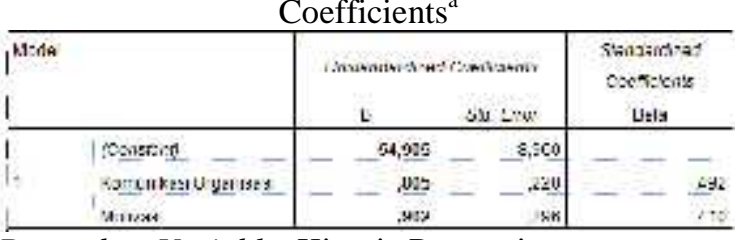

Dependent Variable: Kinerja Pegawai

Sumber: hasil pengolahan data (SPSS versi 20).

Berdasarkan hasil pengolahan data pada tabel di atas diperoleh model persamaan $\hat{\mathrm{Y}}=54,905+$ $0,805 \mathrm{X}_{1}+0,902 \mathrm{X}_{2}$ diartikan bahwa terdapat pengaruh yang positif antara variabel komunikasi organisasi $\left(\mathrm{X}_{1}\right)$ dan motivasi $\left(\mathrm{X}_{2}\right)$ terhadap variabel kinerja pegawai (Y) pada Kantor Dinas Sosial dan Tenaga Kerja Kota Pematangsiantar.

\section{2) Koefisien Korelasi dan Koefisien Determinasi}

Selanjutnya dilakukan perhitungan korelasi berupa derajat atau kedalaman hubungan fungsional yang menjelaskan hubungan antar perubah, dinyatakan dengan yang dinamakan koefisien korelasi atau yang sering disimbolkan dengan r. Nilai $r$ dapat dihitung menggunakan SPSS versi 20. Hasil koefisien korelasi dan koefisien determinasi dapat dilihat pada tabel berikut ini:

Tabel 4

Hasil Koefisien Korelasi dan Determinasi

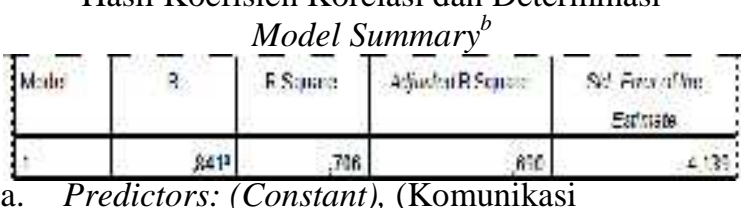

Organisasi) (Motivasi)

b. Dependent Variabel: (Kinerja Pegawai)

Sumber: hasil pengolahan data (SPSS versi 20).

Berdasarkan hasil koefisien korelasi pada tabel di atas, diperoleh nilai korelasi $(r)=0,841$, yang artinya terdapat hubungan yang sangat kuat dan positif antara komunikasi organisasi, motivasi, dengan kinerja pegawai pada Kantor Dinas Sosial dan Tenaga Kerja Kota Pematangsiantar, sesuai dengan kriteria tingkat hubungan. Kemudian diperoleh nilai koefisien determinasi $(\mathrm{R})=0,706$, artinya baik tidaknya kinerja pegawai pada Kantor Dinas Sosial dan Tenaga Kerja Kota Pematangsiantar sebesar 70,6\% dapat dijelaskan oleh komunikasi organisasi dan motivasi, sedangkan sisanya sebesar $29,4 \%$ dapat dijelaskan oleh faktor 
lain seperti disiplin, kepemimpinan, lingkungan kerja, kepuasan kerja, dan lain sebagainya.

\section{3) Uji Hipotesis}

\section{a) Uji Simultan (Uji F)}

Pengujian ini dilakukan secara simultan yaitu dilakukan untuk menentukan diterima atau ditolaknya hipotesis, pengujian hipotesis dilakukan untuk mengetahui pengaruh dari variabel komunikasi organisasi dan motivasi terhadap kinerja pegawai secara simultan. Jika $F_{\text {hitung }}>F_{\text {tabel }}$ atau signifikansi $\leq$ 0,05 maka $\mathrm{H}_{0}$ ditolak

Tabel 5

Perkiraan $\mathrm{F}_{\text {hitung }}$ ANOVA ${ }^{a}$

\begin{tabular}{|c|c|c|c|c|c|c|}
\hline vos: & & 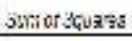 & $\pi$ & Kejo Sosare & $\mathrm{r}$ & Sוב \\
\hline \multirow{3}{*}{1} & Tearessas: & $1<1,07$ & & $\gamma=59$ & $42,11]$ & $.020^{\mathrm{k}}$ \\
\hline & thas cus: & $4 y_{5}, 6 \pm 2$ & & $1: 133$ & & \\
\hline & 7it: & 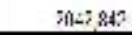 & & & & \\
\hline
\end{tabular}

b. Predictors: (Constant), Komunikasi Organisasi, Motivasi

Sumber: hasil pengolahan data dengan SPSS versi 20 Berdasarkan tabel di atas, diperoleh nilai $F_{\text {hitung }}$ sebesar $42,117>\mathrm{F}_{\text {tabel }}$ dengan $(0,05 ; 2$ vs 35$)$ sebesar 3,27, atau dengan taraf signifikan $0,000<\alpha$ 0,05 , maka $\mathrm{H}_{0}$ ditolak, artinya komunikasi organisasi dan motivasi berpengaruh positif dan signifikan terhadap kinerja pegawai pada Kantor Dinas Sosial dan Tenaga Kerja Kota Pematangsiantar.

\section{b) Uji Parsial (Uji t)}

Pengujian ini dilakukan secara parsial yaitu dilakukan untuk menentukan diterima atau ditolaknya hipotesis, pengujian hipotesis dilakukan untuk mengetahui pengaruh dari variabel komunikasi organisasi dan motivasi terhadap kinerja pegawai secara parsial. Jika $t_{\text {hitung }}>t_{\text {tabel }}$ atau signifikansi $\leq$ 0,05 maka $\mathrm{H}_{0}$ ditolak.

Tabel 6

Perkiraan Nilai $t_{\text {hitung }}$

Coefficients $^{\mathrm{a}}$

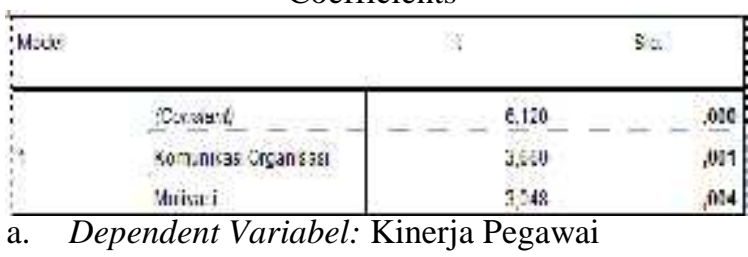

Sumber: hasil pengolahan data dengan SPSS versi 20

Berdasarkan tabel di atas, diperoleh nilai $t_{\text {hitung }}$ pada variabel $X_{1}$ (komunikasi organisasi) sebesar $3,660>$ dari $\mathrm{t}_{\text {tabel }}$ dengan $\mathrm{df}=\mathrm{n}-\mathrm{k}-1$ (38-2-1) sebesar 2,0301, atau dengan taraf signifikan $0,001<\alpha 0,05$, maka $\mathrm{H}_{0}$ ditolak, artinya komunikasi organisasi berpengaruh positif dan signifikan terhadap kinerja pegawai pada Kantor Dinas Sosial dan Tenaga Kerja Kota Pematangsiantar. Untuk variabel $\mathrm{X}_{2}$ (motivasi) diperoleh nilai $t_{\text {hitung }}$ sebesar 3,048 $>$ dari $t_{\text {tabel }}$ dengan $\mathrm{df}=\mathrm{n}-\mathrm{k}-1$ (38-2-1) sebesar 2,0301, atau dengan taraf signifikan $0,004<\alpha 0,05$, maka $\mathrm{H}_{0}$ ditolak, artinya motivasi berpengaruh positif dan signifikan terhadap kinerja pegawai pada Kantor Dinas Sosial dan Tenaga Kerja Kota Pematangsiantar.

\section{Evaluasi}

a. Komunikasi Organisasi Pada Kantor Dinas Sosial dan Tenaga Kerja Kota Pematangsiantar

Berdasarkan dimensi yang digunakan dan hasil penelitian yang diperoleh dapat dijelaskan bahwa komunikasi organisasi yang ada pada Kantor Dinas Sosial dan Tenaga Kerja Kota Pematangsiantar sudah dalam kategori setuju, hal ini dapat dilihat dari segi komunikasi ke bawah, komunikasi ke atas, komunikasi horizontal, dan komunikasi lintas saluran. Hal tersebut dibuktikan dari nilai rata-rata keseluruhan yang dihasilkan sebesar 4,14 dengan kriteria jawaban setuju. Namun masih ada beberapa aspek-aspek walaupun sudah dalam kriteria setuju tetapi masih rendah dibawah nilai rata-rata.

Pertama pada indikator penyampaian pesan dari atasan dan informasi yang disampaikan oleh pegawai memperoleh nilai rata-rata 4,03 , cara untuk mengatasi hal tersebut adalah dengan saling memperhatikan kebutuhan yang diinginkan oleh pimpinan maupun kebutuhan yang diinginkan oleh pegawai. Selanjutnya, pada indikator penyampaian instruksi dari atasan mendapat nilai rata-rata 4,16 , cara untuk mengatasi hal tersebut adalah dengan memahami terlebih dahulu informasi yang hendak disampaikan kemudian melakukan sesuai dengan intruksi yang diberikan oleh pimpinan.

Berikutnya, pada indikator penyampaian masalah pegawai memperoleh nilai rata-rata 4,05 , cara untuk mengatasi hal tersebut yaitu sebaiknya pimpinan lebih bersikap peduli terhadap masalah pekerjaan yang disampaikan pegawai. Pada indikator partisipasi pegawai pada saat rapat mendapat nilai rata-rata 4,13. Agar kegiatan komunikasi dalam rapat bisa terlaksana dengan baik, sebaiknya pegawai menerapkan komunikasi organisasi secara terbuka dengan atasan dalam menyampaikan pendapatnya.

Pada indikator interaksi dengan rekan kerja di bagian lain memperoleh nilai 3,97. Agar interaksi dengan rekan kerja tersebut dapat terjalin lebih harmonis, sebaiknya pegawai lebih mempererat hubungan komunikasi dengan rekan kerjanya di dalam kantor. Kemudian, pada indikator bertukar pikiran dengan rekan kerja di bagian lain apabila ada hal yang perlu untuk ditindak lanjuti didapat nilai rata-rata sebesar 4,07. Untuk mengatasi hal tersebut, sebaiknya pegawai perlu meningkatkan sikap kerjasama dalam bekerja.

\section{b. Motivasi Pada Kantor Dinas Sosial dan \\ Tenaga Kerja Kota Pematangsiantar}

Motivasi yang ada pada Kantor Dinas Sosial dan Tenaga Kerja Kota Pematangsiantar sendiri sudah terlaksana dengan baik, hal ini dapat terlihat dari hasil kuesioner yang dibagikan kepada responden mendapat nilai rata-rata 4,38 dengan kriteria jawaban sangat sangat setuju. Namun, masih ada beberapa aspek yang walaupun dinilai baik tetapi masih rendah dari aspek-aspek indikator yang lain. Pertama pada indikator prestasi di tempat kerja memperoleh nilai rata-rata 4,13 dengan kriteria 
jawaban setuju, cara untuk mengatasi hal ini sebaiknya pimpinan memberikan apresiasi atau penghargaan yang lebih baik lagi kepada pegawai agar pegawai lebih termotivasi untuk meningkatkan prestasi kerjanya. Selanjutnya, pada indikator kesanggupan menghadapi tantangan pekerjaan untuk meraih jabatan tertentu memperoleh nilai 4,15 dengan kriteria jawaban setuju, cara untuk mengatasi hal ini sebaiknya pendidikan dan pelatihan untuk para pegawai lebih rutin dilaksanakan agar pegawai memiliki wawasan dan pengetahuan yang luas untuk menghadapi tantangan pekerjaan.

\section{c. Kinerja Pegawai Pada Kantor Dinas Sosial dan Tenaga Kerja Kota Pematangsiantar}

Dimensi kinerja pegawai pada Kantor Dinas Sosial dan Tenaga Kerja Kota Pematangsiantar dikatakan sangat baik, hal ini dapat dilihat dari hasil kuesioner yang dibagi kepada responden secara keseluruhan memperoleh nilai rata-rata sebesar 4,47.

Berdasarkan nilai rata-rata di atas, terdapat beberapa dimensi pada Kantor Dinas Sosial dan Tenaga Kerja Kota Pematangsiantar yang harus menjadi perhatian seperti dimensi kualitas, disiplin, dan kepemimpinan. Pertama, dimensi kualitas dengan indikator tingkat mutu hasil kerja memperolah nilai rata-rata 4,18 dengan kriteria jawaban baik. Cara untuk mengatasinya yaitu pegawai diharapkan meningkatkan keefektifan kerjanya dan lebih memperhatikan kembali pekerjaan yang telah dikerjakan sehingga memperoleh kualitas kerja yang baik.

Selanjutnya, pada dimensi disiplin dengan indikator tingkat kehadiran pegawai memperoleh nilai rata-rata sebesar 3,95 dengan kriteria jawaban baik. Cara untuk mengatasinya adalah pegawai diharapkan meningkatkan rasa tanggungjawabnya terhadap pekerjaan sehingga pegawai akan termotivasi untuk hadir bekerja. Kemudian, untuk dimensi kepemimpinan dengan indikator kemampuan meyakinkan pegawai lain untuk melaksanakan tugas tambahan memperoleh nilai rata-rata 4,00 dengan kriteria jawaban baik, dan cara mengatasinya adalah pegawai menjaga hubungan kerja yang baik dengan rekan kerja.

\section{KESIMPULAN DAN SARAN}

\section{Kesimpulan}

a. Hasil analisis deskriptif kualitatif tentang komunikasi organisasi berdasarkan dimensi komunikasi ke bawah, komunikasi ke atas, komunikasi horizontal, dan komunikasi lintas saluran memperoleh nilai rata-rata jawaban keseluruhan sebesar 4,14 dengan kriteria setuju. Kemudian nilai rata-rata tertinggi sebesar 4,28 dengan kriteria nilai sangat setuju pada dimensi komunikasi horizontal dengan indikator berbagi informasi pekerjaan dengan rekan kerja satu bagian. Sedangkan nilai rata-rata terendah sebesar 3,97 dengan kriteria nilai setuju pada dimensi komunikasi lintas saluran dengan indikator interaksi dengan rekan kerja di bagian lain. b. Hasil analisis deskriptif kualitatif tentang motivasi berdasarkan dimensi kebutuhan akan prestasi, kebutuhan akan afiliasi, dan kebutuhan akan kekuasaan memperoleh nilai rata-rata jawaban keseluruhan sebesar 4,38 dengan kriteria jawaban sangat setuju. Kemudian nilai rata-rata tertinggi sebesar 4,71 dengan kriteria nilai sangat setuju pada dimensi kebutuhan akan prestasi dengan indikator potensi yang dimiliki dalam bekerja demi mencapai prestasi kerja. Sedangkan nilai rata-rata terendah sebesar 4,13 dengan kriteria nilai setuju pada dimensi kebutuhan akan prestasi dengan indikator prestasi di tempat kerja.

c. Hasil analisis deskriptif kualitatif tentang kinerja pegawai berdasarkan dimensi kuantitas, kualitas, waktu, biaya, orientasi pelayanan, integritas, komitmen, disiplin, kerjasama, kepemimpinan memperoleh nilai rata-rata jawaban keseluruhan sebesar 4,47 dengan kriteria nilai sangat baik. Kemudian nilai rata-rata tertinggi sebesar 4,84 dengan kriteria nilai sangat baik pada dimensi integritas dengan indikator konsistensi dalam bekerja. Sedangkan nilai rata-rata terendah sebesar 3,95 dengan kriteria nilai baik pada dimensi disiplin dengan indikator tingkat kehadiran pegawai.

d. Hasil analisis regresi linear berganda yang dihitung melalui program SPSS versi 20 adalah sebagai berikut $\hat{\mathrm{Y}}=54,905+0,805 \mathrm{X}_{1}+0,902 \mathrm{X}_{2}$, artinya terdapat pengaruh yang positif antara komunikasi organisasi $\left(\mathrm{X}_{1}\right)$ dan motivasi $\left(\mathrm{X}_{2}\right)$ terhadap variabel kinerja pegawai (Y) pada Kantor Dinas Sosial dan Tenaga Kerja Kota Pematangsiantar.

e. Hasil analisis korelasi diperoleh nilai $\mathrm{r}=0,841$, artinya terdapat hubungan yang sangat kuat dan positif antara komunikasi organisasi $\left(\mathrm{X}_{1}\right)$, motivasi $\left(\mathrm{X}_{2}\right)$, dengan kinerja pegawai $(\mathrm{Y})$ pada Kantor Dinas Sosial dan Tenaga Kerja Kota Pematangsiantar. Kemudian, diperoleh nilai koefisien determinasi $(\mathrm{R})=0,706$, artinya baik tidaknya kinerja pegawai pada Kantor Dinas Sosial dan Tenaga Kerja Kota Pematangsiantar sebesar 70,6\% dapat dijelaskan oleh komunikasi organisasi dan motivasi, sedangkan sisanya sebesar 29,4\% dapat dijelaskan oleh faktor lain seperti disiplin, kepemimpinan, lingkungan kerja, kepuasan kerja, dan lain sebagainya.

f. Hasil uji hipotesis secara simultan, diperoleh nilai $F_{\text {hitung }}$ sebesar 42,117 sedangkan $F_{\text {tabel }}$ dengan $(0,05 ; 2$ vs 35$)$ sebesar 3,27 , atau taraf signifikan sebesar $0,000<\alpha 0,05$, maka $\mathrm{H}_{0}$ ditolak, artinya komunikasi organisasi dan motivasi berpengaruh positif dan signifikan terhadap kinerja pegawai pada Kantor Dinas Sosial dan Tenaga Kerja Kota Pematangsiantar secara simultan.

g. Hasil uji hipotesis secara parsial, diperoleh nilai $t_{\text {hitung }}$ pada variabel komunikasi organisasi $\left(X_{1}\right)$ sebesar 3,660 sedangkan $\mathrm{t}_{\text {tabel }}$ dengan $\mathrm{df}=\mathrm{n}-\mathrm{k}-1$ $(38-2-1=35)$ sebesar 2,0301, atau taraf signifikan $0,001<\alpha 0,05$, maka $\mathrm{H}_{0}$ ditolak, artinya komunikasi organisasi berpengaruh positif dan signifikan terhadap kinerja pegawai pada Kantor 
Dinas Sosial dan Tenaga Kerja Kota Pematangsiantar. Sedangkan untuk variabel motivasi $\left(\mathrm{X}_{2}\right)$ diperoleh nilai $\mathrm{t}_{\text {hitung }}$ sebesar 3,048 $>$ dari $\mathrm{t}_{\text {tabel }}$ dengan $\mathrm{df}=\mathrm{n}-\mathrm{k}-1 \quad(38-2-1=35)$ sebesar 2,0301 , atau taraf signifikan $0,004<\alpha 0,05$, maka $\mathrm{H}_{0}$ ditolak, artinya motivasi berpengaruh positif dan signifikan terhadap kinerja pegawai pada Kantor Dinas Sosial dan Tenaga Kerja Kota Pematangsiantar.

\section{Saran}

a. Komunikasi organisasi yang ada pada Kantor Dinas Sosial dan Tenaga Kerja Kota Pematangsiantar dapat berjalan dengan efektif, sebaiknya pimpinan lebih bersikap peduli terhadap masalah pekerjaan yang disampaikan pegawai, pegawai menerapkan komunikasi organisasi secara terbuka dengan atasan dalam menyampaikan pendapatnya, pegawai lebih mempererat hubungan komunikasi dengan rekan kerjanya, dan meningkatkan sikap kerjasama dalam bekerja.

b. Motivasi yang ada pada Kantor Dinas Sosial dan Tenaga Kerja Kota Pematangsiantar dapat terlaksana dengan baik, sebaiknya pimpinan memberikan apresiasi atau penghargaan kepada para pegawai yang memiliki prestasi di tempat kerja, pendidikan dan pelatihan kerja untuk para pegawai sebaiknya rutin dilaksanakan agar pegawai memiliki wawasan dan pengetahuan yang luas untuk menghadapi tantangan pekerjaan.

c. Kinerja pegawai yang ada pada Kantor Dinas Sosial dan Tenaga Kerja Kota Pematangsiantar menghasilkan kinerja yang optimal, sebaiknya pegawai meningkatkan keefektifan kerjanya serta memperhatikan kembali pekerjaan yang telah dikerjakan sehingga memperoleh kualitas kerja yang baik, pegawai meningkatkan rasa tanggungjawabnya terhadap pekerjaan sehingga pegawai akan termotivasi untuk hadir bekerja, dan pegawai menjaga hubungan kerja yang baik dengan rekan kerja. d. Sehubungan dengan keterbatasan-keterbatasan yang ada pada penulis, penelitian ini masih terdapat kelemahan-kelemahan dan belum dapat mengungkap seluruh variabel yang dapat mempengaruhi kinerja pegawai pada Kantor Dinas Sosial dan Tenaga Kerja Kota Pematangsiantar. Sebagai bahan masukan untuk penelitian selanjutnya, maka perlu memperbanyak variabel penelitian, seperti: disiplin, kepemimpinan, lingkungan kerja, kepuasan kerja, dan lain sebagainya.

\section{E. DAFTAR PUSTAKA}

Bangun, Wilson. 2012. Manajemen Sumber Daya Manusia. Jakarta: Erlangga.

Dessler, Gary. 2004. Manajemen Sumber Daya Manusia. Jakarta: Prenhallindo.

Gomes, Faustino Cordoso. 2003. Manajemen Sumber Daya Manusia, Edisi 2. Yogyakarta: Andi.

Handoko, T. Hani. 2002. Manajemen Personalia dan Sumber Daya Manusia. Yogyakarta: BPFE.

Luthans, Fred. 2006. Perilaku Organisasi, Edisi 10. Yogyakarta: Andi.

Mathis, Robert L dan John H Jackson. 2006. Manajemen Sumber Daya Manusia, Edisi Kesepuluh. Jakarta: Salemba Empat.

Mondy, R. Wayne. 2008. Manajemen Sumber Daya Manusia, Edisi 10, Jilid I. Jakarta: Erlangga.

Pace, R. Wayne dan Don F Faules. 2006. Komunikasi Organisasi. Bandung: PT Remaja Rosdakarya.

Peraturan Pemerintah Nomor 46 Tahun 2011 tentang Penilaian Prestasi Kerja Pegawai Negeri Sipil.

Robbins, Stephen P. 2003. Manajemen Jilid I. Jakarta: PT.Indeks.

Robbins, Stephen P dan Mary Coulter. 2010. Manajemen, Edisi Kesepuluh, Jilid 2. Jakarta: Erlangga. 